\title{
32. GEOTHERMAL OBSERVATIONS DURING DEEP SEA DRILLING PROJECT LEG 78A ${ }^{1}$
}

\author{
D. M. Davis, Massachusetts Institute of Technology \\ and \\ D. M. Hussong, Hawaii Institute of Geophysics²
}

\begin{abstract}
During DSDP Leg 78A, temperatures were measured on both sides of the deformation front at the eastern boundary of the Caribbean Plate. Although attempts to measure temperatures were plagued by difficulties with equipment and by drill-hole stability problems, some noteworthy measurements of extraordinarily high temperatures were obtained. Downhole logging at Site 543 to the east of the deformation front yielded a heat-flow value somewhat low for typical Upper Cretaceous crust, whereas a temperature sensor in the Hawaii Institute of Geophysics (HIG) downhole seismic package yielded a value higher than expected. Measurements at Site 541 in the accretionary prism yielded values as high as $15^{\circ} \mathrm{C}$ at 50 to $100 \mathrm{~m}$ sub-bottom. We speculate that these extraordinarily high temperatures are related to upward migration of warm water from greater depths, possibly related to extreme overpressures maintained by tectonic compaction during subduction and formation of the accretionary trench slope.
\end{abstract}

\section{INTRODUCTION}

Coring on Leg 78A sampled the convergent margin and accretionary prism at the eastern boundary of the Caribbean Plate. Samples and downhole measurements from sites a short distance on either side of the deformation front (Fig. 1) afforded an exceptional opportunity to study convergence processes. The temperature distribution in the overriding plate at convergent margins is not well known, because measurements are few and often unreliable. Rapid and irregular sediment accumulation rates, often involving mass transport of bottom material and complex structural and tectonic settings, contribute to the difficulty of interpreting the geothermal data. These data are essential, however, both for understanding the geology of active margins and for satisfying considerations of safety when drilling.

\section{METHODS}

Temperature measurements, using three different types of instruments, were attempted at all three sites of Leg 78A. During interludes in the drilling of Hole 541, the Tokyo T-probe (Yokota et al., 1980; Uyeda and Horai, 1982) was used to measure temperatures at the bottom of the hole. The probe was kept in the mud at the bottom of the hole until the measured temperature approached an equilibrium value. Two of three attempted measurements succeeded in providing individual temperature data points; but unexplained jumps in the records render both of these data points suspect.

A Gearhart-Owen temperature log was also run at each site. Ideally, such temperature logging should provide a profile of temperature as a function of depth in the hole. But, difficulties involving hole instability and sticking of the drill pipe severely limited the distance the tool could move past the end of the pipe. This in turn limited our acquisition of useful data, particularly at Sites 541 and 542 in the accretionary prism.

The HIG downhole seismic experiment carried a temperature sensor not affected by the high-frequency, electronics-generated noise that in-

\footnotetext{
${ }^{1}$ Biju-Duval, B., Moore, J. C., et al., Init. Repts. DSDP, 78A: Washington (U.S. Govt. Printing Office).

2 Addresses: (Davis, present address) 220 Seismology Bldg., Lamont-Doherty Geological Observatory, Palisades, NY 10964; (Hussong) Hawaii Institute of Geophysics, Honolulu, HI.
}

terfered with its recording of seismic data. The HIG instrument was deployed in Hole 543. It provided a single temperature data point for the bottom of the hole.

\section{RESULTS}

\section{Site 541}

Temperature measurements in Hole 541 included two T-probe measurements of highly dubious reliability and a Gearhart-Owen temperature log, which extended to only a few meters below the bottom of the pipe before the logging device was stopped by obstructions in the hole.

The first T-probe temperature measurement in Hole 541 (Fig. 2) was made at a depth of $48.5 \mathrm{~m}$ sub-bottom, and the second (Fig. 3) was made at $95 \mathrm{~m}$ sub-bottom. A third measurement was attempted at $143.5 \mathrm{~m}$, but was not successful. These measurements have some inherent uncertainties, including the possibility of frictional heating as a result of incompletely compensated ship-heave (Uyeda and Horai, 1982). In addition, there are unexplained jumps in the records (at $19 \mathrm{~min}$. in Fig. 2 and at 12 and 18 min. in Fig. 3), which cast serious doubts upon the reliability of these measurements. The two measurements appear to converge upon equilibrium temperatures of approximately $16.2^{\circ} \mathrm{C}$ (at $48.5 \mathrm{~m}$ sub-bottom) and $15.5^{\circ} \mathrm{C}$ (at $95 \mathrm{~m}$ sub-bottom).

The Gearhart-Owen downhole logging device descended only $10 \mathrm{~m}$ past the bottom of the pipe before it was blocked by an obstruction below which it could not proceed. This obstruction, probably a result of deformation and infall of hole-wall material, was the first of several hole-stability problems encountered during Leg 78A. A second logging attempt was aborted because of a malfunction, and a third was stopped by another obstruction in the hole.

The inability of the logging device to measure temperatures more than a short distance past the end of the pipe makes it impossible to construct a true temperature profile for Hole 541. A logging trip which barely exits 


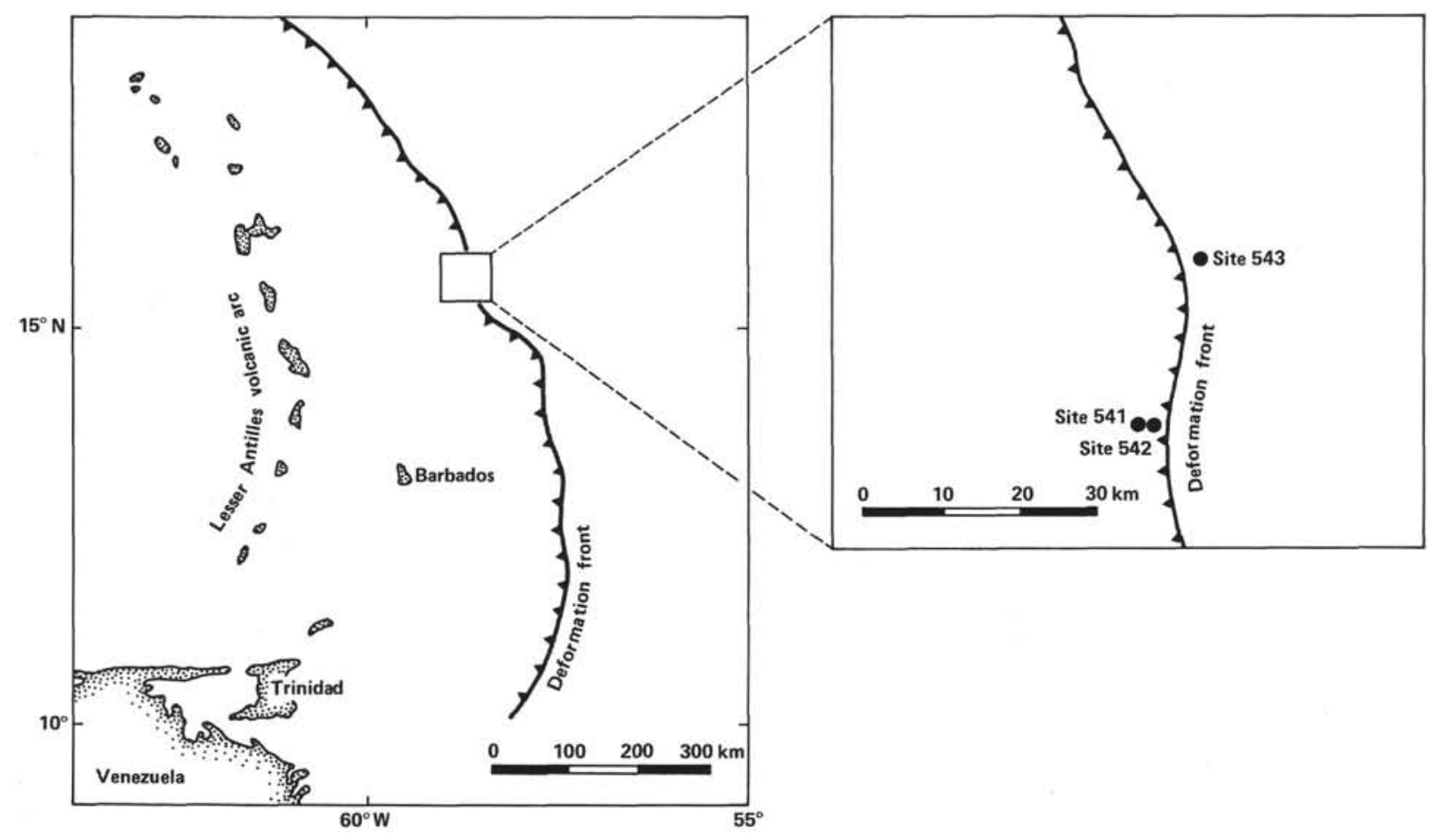

Figure 1. Map of the Leg 78A drilling area. Note that Sites 541 and 542 are on the overthrusting (Caribbean) plate and Site 543 is on the Atlantic Ocean side of the deformation front.

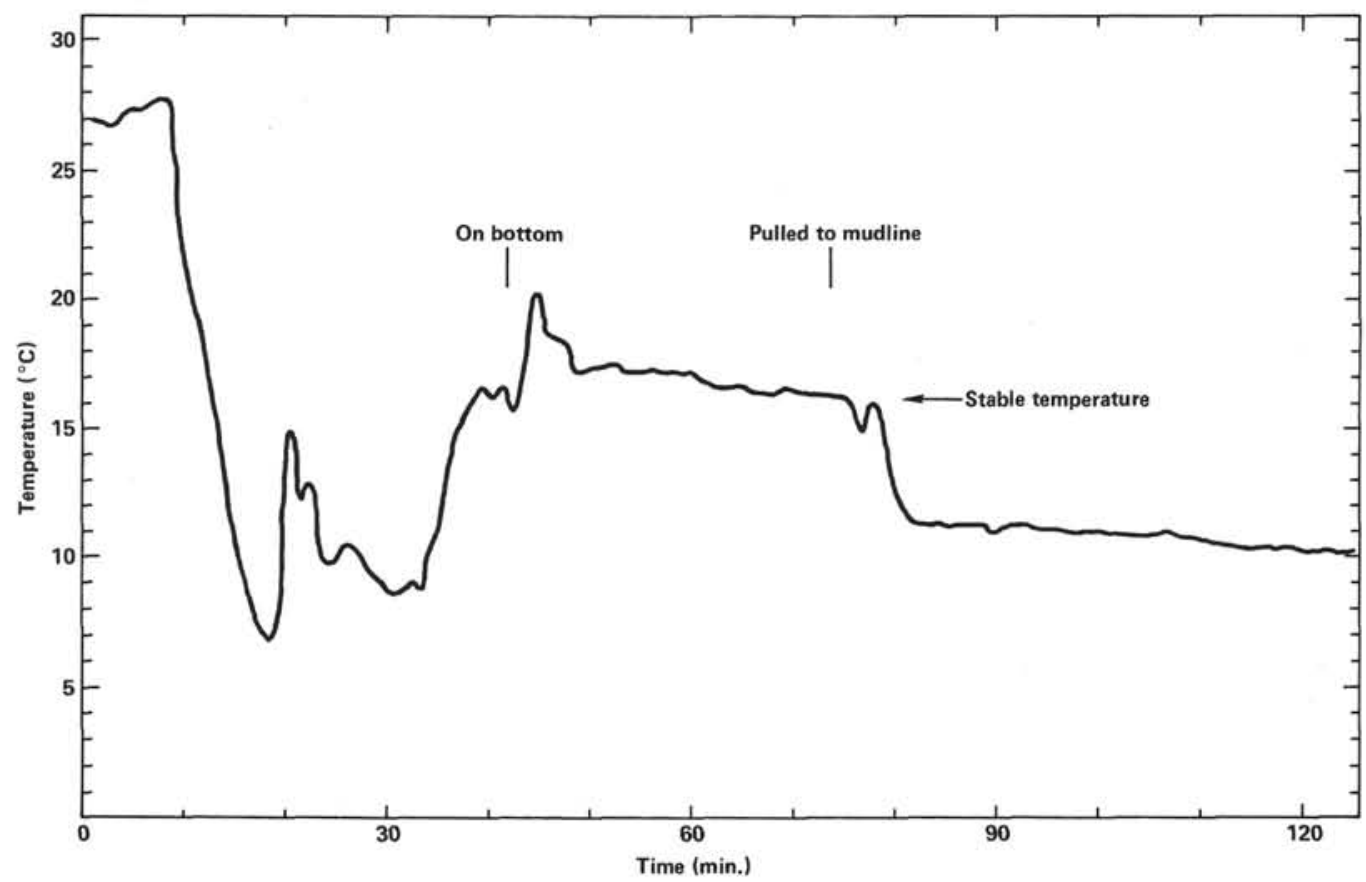

Figure 2. Plot of recorded temperature vs. time for the Tokyo T-probe at a depth of $48.5 \mathrm{~m}$ sub-bottom in Hole 541.

the pipe yields, at best, a single decipherable temperature-depth data point. Temperature measurements for this hole (Fig. 4) are dominated by pipe-related effects. The instrument recorded a sharp temperature increase from $2.5^{\circ} \mathrm{C}$ to roughly $5^{\circ} \mathrm{C}$ within $10 \mathrm{~m}$ of the mudline. This apparently represents a boundary region-in the top few meters below the sea floor, where the hole is considerably wider than the pipe diameter-separating cold seawater and warmer water from below.

The relatively constant temperatures measured from $10 \mathrm{~m}$ sub-bottom to the bottom of the pipe are probably related to the flow of water in and around the pipe, and 


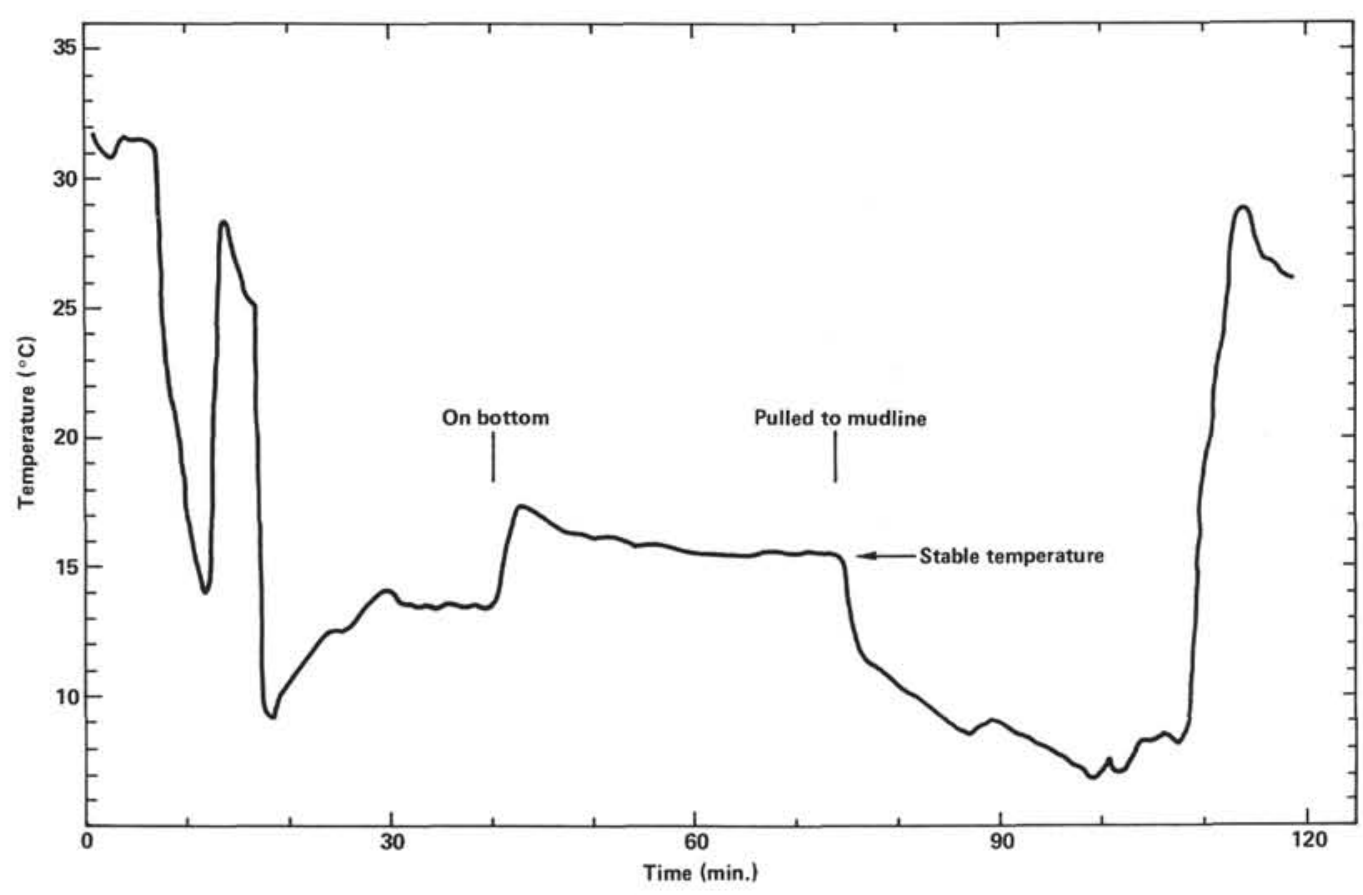

Figure 3. Plot of recorded temperature vs. time for the Tokyo T-probe at a depth of $95 \mathrm{~m}$ sub-bottom in Hole 541 . Note the slow drop-off in temperature after the probe was lifted out of mud sticking to the instrument.

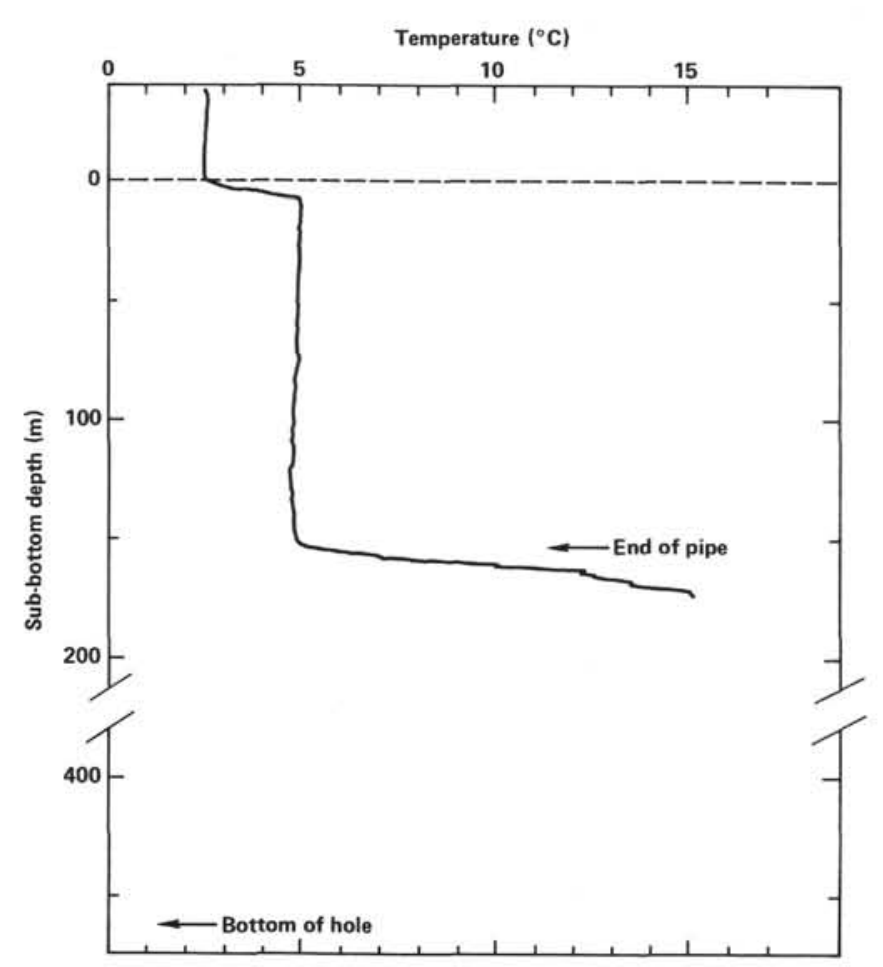

Figure 4. Temperature measured as a function of depth by GearhartOwen downhole logging device in Hole 541 .

do not directly indicate the true undisturbed thermal gradient. The temperatures measured by the logging device increased by $10^{\circ} \mathrm{C}$ in the first $20 \mathrm{~m}$ below the pipe. This would appear to be a boundary layer between the pipe, which had been cooled by pumping of cold water during deployment of the logging device, and the relatively unaffected parts of the hole-well below the pipe-which had not undergone circulation of cold water since several hours earlier. By the time the device hit an obstruction in the hole and could proceed no further, the temperature had reached $15^{\circ} \mathrm{C}$. The logged rate of temperature increase with depth had at this point diminished, but remained rather steep, suggesting that the logging device had passed most, but not all, of the way through the region of the hole disturbed by pipe-end thermal effects. Assuming that the temperature had not been affected since the last circulation to total depth (30 min. in duration, roughly $51 / 2 \mathrm{hrs}$. earlier), we can use the analysis of Jaeger (1961) to determine what fraction of that circulation-induced temperature disturbance still remained. This analysis indicates that the temperature had recovered $70 \%$ of the way to its pre-disturbance value. Given a conservative estimate of $15.0^{\circ} \mathrm{C}$ for the hole temperature just beyond the influence of pumping in the pipe, this yields an undisturbed temperature of $20.4^{\circ} \mathrm{C}$ in the hole at a depth of roughly $170 \mathrm{~m}$ sub-bottom. The total penetration depth of drilling in this hole is $459 \mathrm{~m}$, and there was evidently at least some upward movement of warm water within the hole. It is therefore not clear whether this temperature indicates the pre-drilling temperature at the depth where the measurements were taken or reflects, instead, the in-hole convection of warm water from a more highly overpressured zone near the base of the hole.

\section{Site $\mathbf{5 4 2}$}

There were no successful temperature measurements at Site 542. When the pipe became stuck in Hole 542B, an explosive charge was detonated in the pipe to try to 
recover as much as possible of the bottom-hole assembly. This charge did not achieve its purpose, but instead blew a hole in the drill string. A Gearhart-Owen temperature log was run in the pipe (Fig. 5) down to the depth of the explosion, where the instrument was apparently stopped by shredded metal.

A rapid increase in temperature at the deepest point in the logging run suggests that at the explosion site the logging device encountered warm water flowing up from below and then out of the hole that had been blown in the pipe. The more gradual increase in temperature with depth above that point probably had less to do with the thermal gradient outside the pipe than with the influence of water circulation in the pipe. The maximum temperature recorded $\left(9.8^{\circ} \mathrm{C}\right)$ can be regarded as an absolute minimum estimate of the temperature at some point between the measurement depth and the bottom of the hole. Without better knowledge of the role of convection in the pipe and without knowing the exact location of the hole blown in the pipe, no firm estimates of the thermal gradient at this site are possible.

\section{Site $\mathbf{5 4 3}$}

Site 543 was the only Leg 78A site located seaward of the deformation front. The downhole temperature log for Hole 543A (Fig. 6) shows a rapid temperature in-

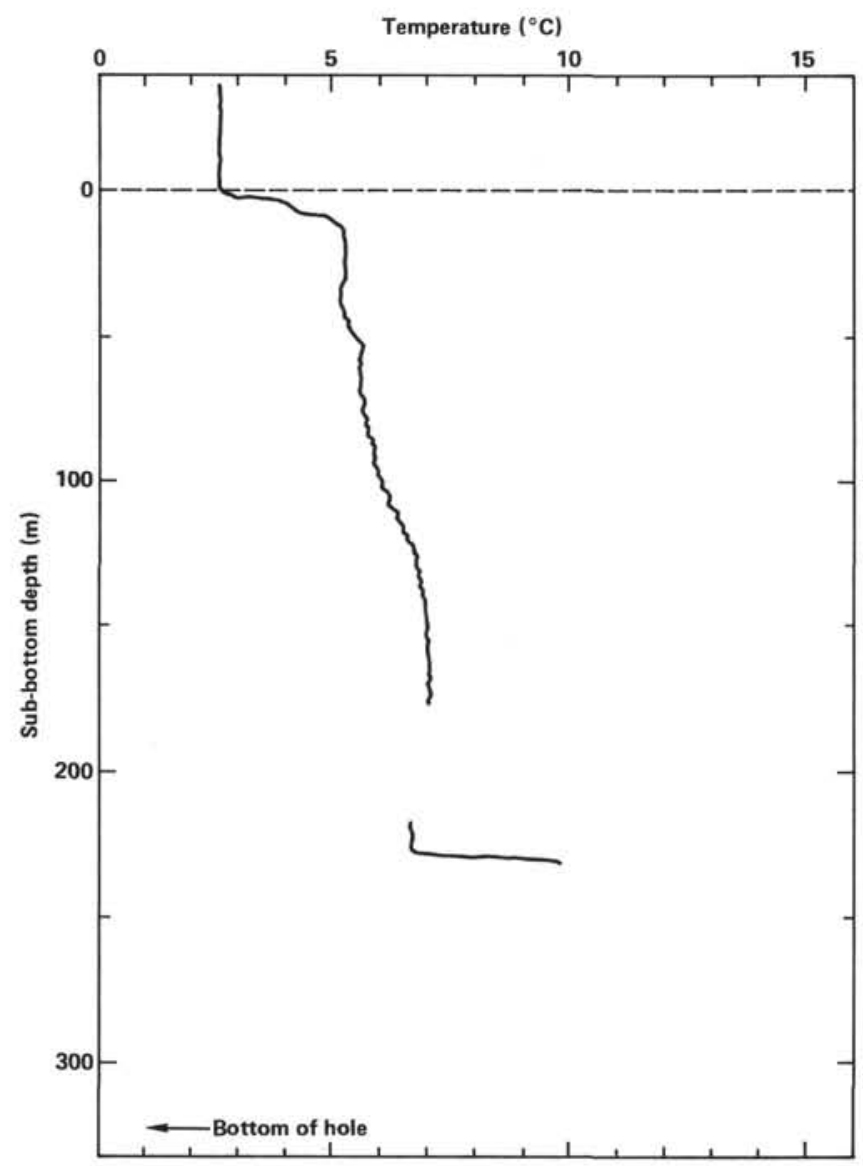

Figure 5. Temperature measured as a function of depth by GearhartOwen downhole logging device in Hole 542B.

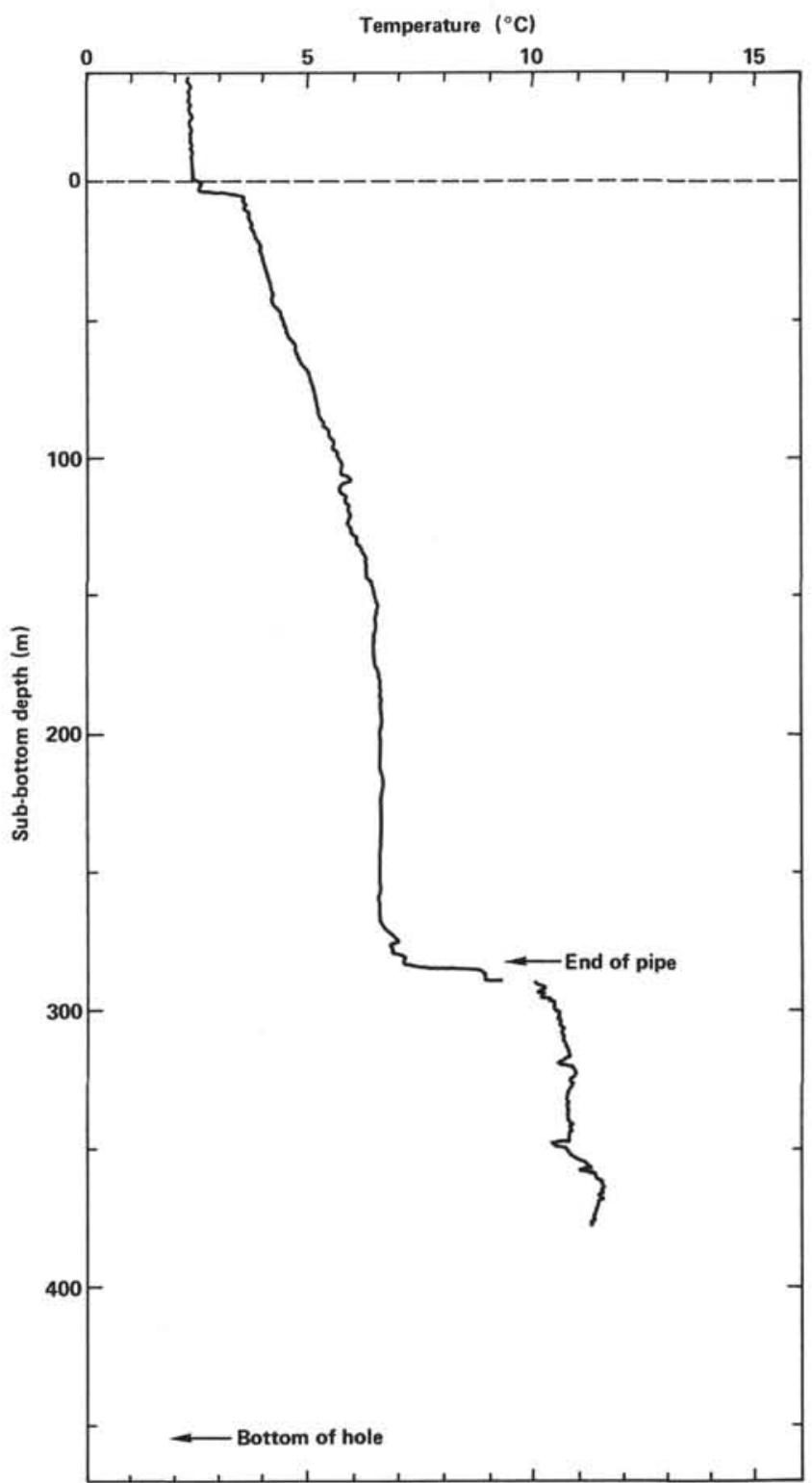

Figure 6. Temperature measured as a function of depth by GearhartOwen downhole logging device in Hole 543A.

crease from the bottom of the pipe downward, to $11^{\circ} \mathrm{C}$. Although cool water had circulated in the pipe only a short while before the logging run, the last circulation to total depth (roughly $1 / 2 \mathrm{hr}$. in duration) had been 11 hrs. earlier. Well beyond the pipe, the hole should have nearly returned to its undisturbed temperature. Using the method of Jaeger (1961), we find that the temperature had recovered from all but $28 \%$ of the pumping-induced thermal disturbance. The measured temperature of $11.4^{\circ} \mathrm{C}$ past the pipe at $377 \mathrm{~m}$ below the seafloor should then correspond to an undisturbed temperature of $14.9^{\circ} \mathrm{C}$ and a mean thermal gradient of $3.0^{\circ} \mathrm{C} / 100 \mathrm{~m}$. Because of our assumptions about the time elapsed since the last thermal disturbance, these values must be regarded as lower bounds.

The temperature sensor included in the package for the HIG downhole seismometer experiment in Hole 543A 
yielded somewhat higher values. From the time the instrument was emplaced at $455 \mathrm{~m}$ sub-bottom (beneath $411 \mathrm{~m}$ of sediment and $44 \mathrm{~m}$ of basalt pillow lavas) at 0130 hours on 8 March until it was removed at 1800 hours on 9 March, the temperature rose steadily (Fig. 7). In those $28.5 \mathrm{hrs}$. the temperature rose from $15^{\circ} \mathrm{C}$ to $21^{\circ} \mathrm{C}$. Considering results from the longer-term deployment of a similar instrument in Hole 494A off Guatemala (Carter et al., in press), we conservatively estimate that the temperature in the bottom of the hole would have continued to rise to an equilibrium value of about $24^{\circ} \mathrm{C}$. This temperature would then indicate a thermal gradient for Hole $543 \mathrm{~A}$ of approximately $5^{\circ} \mathrm{C} / 100 \mathrm{~m}$.

\section{DISCUSSION AND CONCLUSIONS}

The temperature measurements on Leg 78A were complicated by hole-stability problems. It is clear, however, that surprisingly high temperatures exist at the drilling sites, particularly at Site 541 .

The downhole temperature log for Site 543, seaward of the deformation front, is consistent with a geothermal gradient of at least $3.0^{\circ} \mathrm{C} / 100 \mathrm{~m}$. Given a thermal conductivity of $2.5 \times 10^{-3} \mathrm{mcal} /{ }^{\circ} \mathrm{C} \mathrm{cm} \mathrm{s}$ in all but the bottom of the hole (Marlow, this volume), and assuming that conductive heat transfer is predominant, we find a heat flow of $>0.83 \mathrm{HFU}$. Such a value is near the lower end of the range of typical values for oceans over Upper Cretaceous crust (Sclater et al., 1981). A similar result is obtained if we use the higher thermal gradient of $5.0^{\circ} \mathrm{C} /$ $100 \mathrm{~m}$, interpreted from the HIG temperature data, and a higher conductivity of $4.0 \mathrm{mcal} /{ }^{\circ} \mathrm{C} \mathrm{cm} \mathrm{s}$, for the basalt section. The previous heat-flow measurements made nearest the area of Site 543 average 1.26 (Birch, 1970; Schubert and Peter, 1974).
The front of an overthrusting margin is expected to have a relatively low thermal gradient (Toksöz et al., 1971). Observations on the Japan Trench transect (Langseth and Burch, 1980) yield geothermal gradients of 2.4 to $3.6^{\circ} \mathrm{C} / 100 \mathrm{~m}$. Measurements on Leg 66 off the southwestern coast of Mexico (Shipley and Shephard, 1982) indicate gradients of 2.5 to $4.0^{\circ} \mathrm{C} / 100 \mathrm{~m}$.

The very limited data from Site 542 are not necessarily inconsistent with a thermal gradient comparable to those in other accretionary prisms. Site 541, however, appears to be truly anomalous. A temperature of $20.4^{\circ} \mathrm{C}$ at $170 \mathrm{~m}$ sub-bottom, if indicative of the undisturbed temperature at that depth, requires a mean thermal gradient of $10.4^{\circ} \mathrm{C} / 100 \mathrm{~m}$. If the temperature measured just below the bottom of the pipe actually reflects upward movement of warm water from somewhat nearer the bottom of the hole, then the undisturbed thermal gradient would be between that value, 10.4 , and $4.0^{\circ} \mathrm{C} / 100 \mathrm{~m}$. Such a possibility appears to be inconsistent with the highly suspect Tokyo Tprobe measurements, which suggest that most (roughly $13^{\circ} \mathrm{C}$ ) of the temperature increase occurs in the uppermost $50 \mathrm{~m}$ sub-bottom.

However they are interpreted, the Leg 78A data suggest abnormally high thermal gradients in the toe of the accretionary prism. Exceptionally high fluid pressures and geochemical evidence (Claypool, this volume) are consistent with upward migration of warm waters as a heat transfer mechanism.

The source of the warm water at Sites 541 and 542 is unclear. Volcanism is very unlikely because the nearest possible source, the Lesser Antilles arc, is almost $300 \mathrm{~km}$ away. One possible source may be a region near the décollement shear zone somewhat to the west of the deformation front. Nearly lithostatic fluid pressures along this

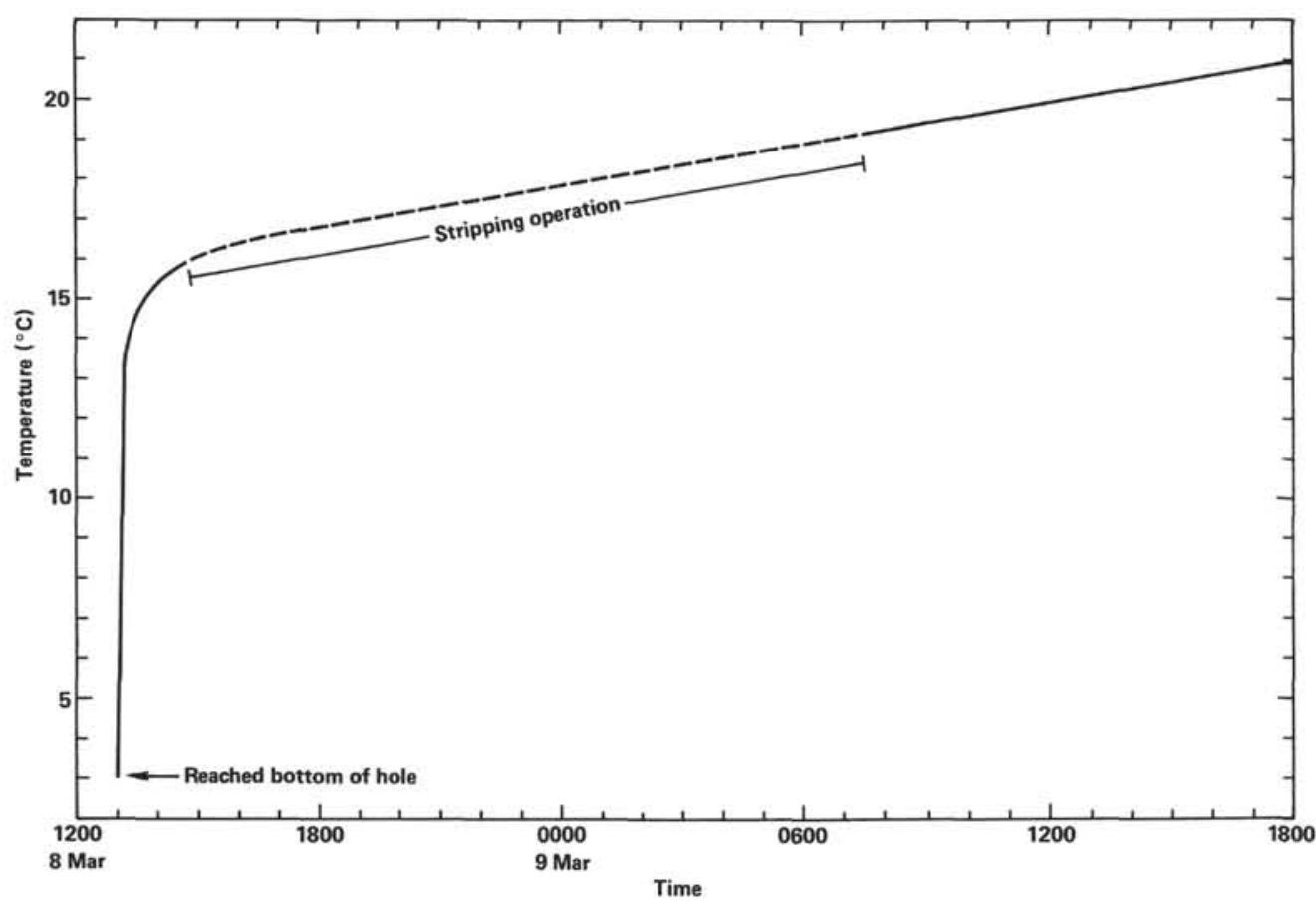

Figure 7. Temperatures observed on the HIG downhole seismometer package in the bottom of Hole 543A. 
zone could provide the fluid-pressure head required to drive the migration of pore fluids. Because of the greater depth of the décollement farther to the west, these upward-migrating fluids should be warm. The intrinsic permeability of the sediments is low, so these fluids would most readily flow upward along fractures. Because of the westward dip of thrust faults in the area, this upward movement would tend to concentrate warm waters to the east, near the toe, where Sites 541 and 542 are located. Tectonic shortening, thickening, and piling-up of overburden may provide a mechanism for maintaining the required fluid-pressure head.

Any further drilling in this area should include very careful thermal, geochemical, and fluid-pressure measurements to verify these high temperatures, to ascertain their sources, and to determine if they are produced by upward migration of fluids produced during subduction by dewatering of sediments.

Documentation of the existence and extent of overpressured fluids in subduction-zone décollement surfaces would be extremely important for understanding subduction processes.

\section{ACKNOWLEDGMENTS}

We thank Marcus Langseth for his review of this manuscript. This work was supported by the Division of Earth Sciences, National Science Foundation, grant EAR 78-12936 (MIT) and by the Office of Naval Research, grant N00014-75-0209.

\section{REFERENCES}

Birch, F. S., 1970. The Barracuda Fault Zone in the western North Atlantic. Deep Sea Res., 17:847-859.

Carter, J. A., Duennebier, F. K., and Hussong, D. M., in press. A comparison between a downhole seismometer and a seismometer on the ocean floor. Bull. Seism. Soc. Am.

Jaeger, J. C., 1961. The effect of the drilling fluid on temperature measured in boreholes. J. Geophys. Res., 66:563-569.

Langseth, M., and Burch, T., 1980. Geothermal observations on the Japan Trench transect. In Scientific Party, Init. Repts. DSDP, 56, 57, Pt. 2: Washington (U.S. Govt. Printing Office), 1207-1010.

Schubert, C. E., and Peter, G., 1974. Heat flow northeast of Guadaloupe Island, Lesser Antilles. J. Geophys. Res., 79:2139-2140.

Sclater, J. G., Parsons, B., and Jaupart, C., 1981. Oceans and Continents: Similarities and differences in the mechanisms of heat loss. J. Geophys. Res., 86:11535-11552.

Shipley, T. H., and Shephard, L. E., 1982. Temperature data from the Mexico drilling area: Report on logging and inhole temperature experiments. In Watkins, J. S., Moore, J. C., et al., Init. Repts. DSDP, 66: Washington (U.S. Govt. Printing Office), 771-774.

Toksöz, M. N., Minear, T. W., and Julian, B. R., 1971. Temperature field and geophysical effects of a downgoing slab. J. Geophys. Res., 76:1113-1138.

Uyeda, S., and Horai, K., 1982. Heat flow measurements on Deep Sea Drilling Project Leg 60. In Hussong, D. M., Uyeda, S., et al., Init. Repts. DSDP, 66: Washington (U.S. Govt. Printing Office), 789-800.

Yokota, T., Kinoshita, H., and Uyeda, S., 1980. New DSDP (Deep Sea Drilling Project) downhole temperature probe using IC RAM (memory) elements. Bull. Earthquake Res. Inst. Tokyo Univ., 55: $75-88$.

Date of Initial Receipt: March 14, 1983

Date of Acceptance: August 24, 1983 